\title{
Iron Smelting in the Nomadic Empire of Xiongnu in Ancient Mongolia
}

\author{
Tomotaka SASADA $^{1) *}$ and Amartuvshin $\mathrm{CHUNAG}^{2)}$ \\ 1) Ehime University, Ehime, Japan. \\ 2) Institute of Archaeology, the Mongolian Academy of Sciences, Ulaanbaatar, Mongolia.
}

(Received on November 30, 2013; accepted on March 3, 2014)

\begin{abstract}
The first archeological evidence in Mongolia of an iron-smelting site has been discovered at Khustyn Bulag. This site belongs to the Xiongnu age (209BCE-155CE). The Xiongnu was the first Nomadic Empire in east Eurasia. Our excavation area was quite small but contained many interesting structures (smelting furnaces, calciners or roasters of iron ore, and slag disposal pits) and artifacts (a few pieces of pottery of Xiongnu age, many clay tuyeres and slag, stone hammers and stone anvil). We could categorize the furnaces into three types, but all of them had slag pits. In addition, several clay tuyeres were used at each furnace. These characteristics of iron smelting are related not to China but to South Siberia. We also performed metallurgical and mineralogical analyses on the slag, clarified the processes of direct steel-making, roasting of iron ore (Magnetite), and found the iron mine that supplied ore to the site. We consider our research results sufficient to undertake a comparative study on Eurasia scale. This iron-smelting technology was introduced into ancient Mongolia from the West through the Steppe-Taiga area and was adjusted and locally developed (or originally), even though iron production was in conflict with the traditional nomadic life-style of the ancient Mongolians. We will continue our research, to clarify the interesting process that led nomadic society to produce political system and establish a nomadic state.
\end{abstract}

KEY WORDS: iron smelting; Xiongnu (209BCE-155CE); Mongolia; nomad; furnace; excavation.

\section{Introduction}

Precisely speaking, the "Metal Road", that connects West Asia and East Asia, is still the missing-link. Recently researchers have focused on the Steppe belt. The Steppe belt plays an important role in the spread of not only metal (iron, copper, bronze), but also horse riding, agriculture, and animal domestication.

Iron is essential to human society. Iron is the symbol that produces power, and military strength and fuels of the empire. Nomadic empires also tried every means to acquire iron too. We have considered the relationship between iron and nomad. Only a few researches have published the results of field works in this area. Only Kh. Perlee described the metallurgical history of nomads in Mongolia on the basis of the rich results of his field work. ${ }^{1)}$ With this information in mind, we started our co-research in 2011, and have already found the first evidence of iron smelting in ancient Mongolia (Fig. 1). At the Khustyn Bulag site, we found iron-smelting furnaces, calciners or roasters of iron ore and slag disposal pits. Therefore, this paper describes iron smelting in Ancient Mongolia, based on the archaeological and metallurgical research.

\footnotetext{
* Corresponding author: E-mail: sasada@ehime-u.ac.jp
} DOI: http://dx.doi.org/10.2355/isijinternational.54.1017

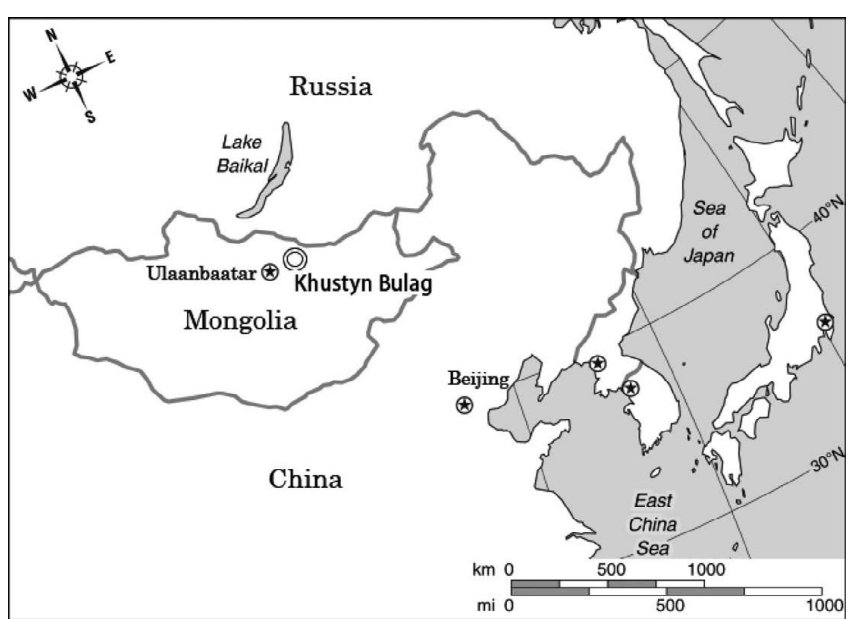

Fig. 1. Location of the Khustyn Bulag site.

\section{Research Project "The History of Mongolian Metal- lurgy"}

In February 2011, the Institute of Archaeology, Mongolian Academy of Sciences (IAMAS) and the Research Center of Ancient East Asian Iron Culture (AIC), Ehime University (Japan) concluded an agreement on a Mongolian and Japanese joint research project entitled "History of Mongolian Metallurgy". This project specializes in metallurgical and archaeological research. Not only do the archaeologists take 


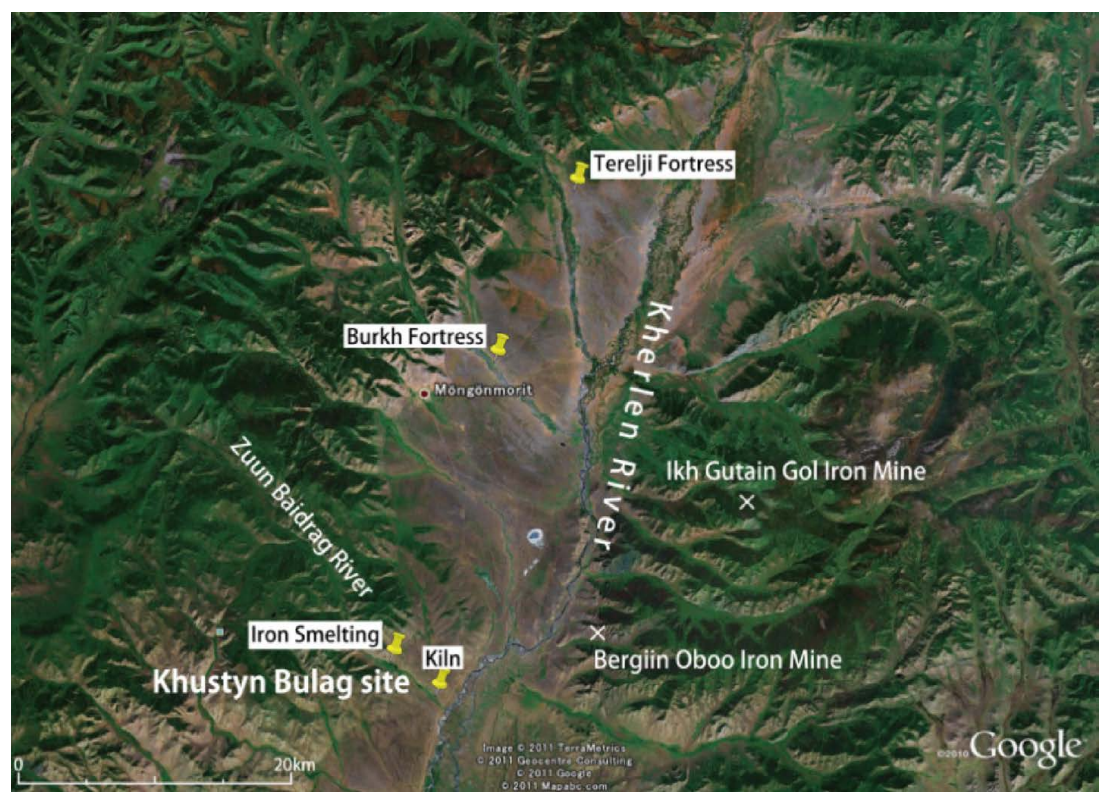

Fig. 2. Around the Khustyn Bulag site. (Online version in color.)

part in the project, but so do geologists and metallurgical analysts. One of its main research expeditions has been along the Zuun Baidlag River, especially the excavation at the Khustyn Bulag site (lat. 48 01' 49.8' N, long. 108 26' 53.5" E, $1380 \mathrm{~m}$ ).

This river is a branch of the Kherlen River, which is located in Mongonmorit Soum of the Tuv Province. At a small spring to the south of a small mountain, which is located in the midst of the river channel with a few birches, is a spring called Khustyn Bulag ("white birches' spring") by the locals. There are hundreds of historical and archaeological sites from the Stone Age to the Medieval Age in this river valley. There are Xiongnu pottery kilns about $4 \mathrm{~km}$ down river from the iron-smelting site. In addition, there are square fortresses belonging to the Xiongnu age, the Khureet Dov fortress is located $18 \mathrm{~km}$ to the south of the iron-smelting site, and the Burkh fortress is located $22 \mathrm{~km}$ to the north of it.

\section{Archaeological Results}

\subsection{Introduction}

Our excavation area was quite small but featured many interesting structures (smelting furnaces, calciner or roaster sites containing iron ore and slag disposal pits) and artifacts (few pieces of potteriy of Xiongnu age, many clay tuyeres and slag, stone hammers and a stone anvil) (Figs. 3 and 4). The excavation was divided into two layers, by the ${ }^{14} \mathrm{C}$ data the $1^{\text {st }}$ century CE upper layer and the $1^{\text {st }}$ century BCE lower layer.

\subsection{Furnace}

We found five iron smelting furnaces (Furnace 1-5). Furnace 1,4 , and 5 were found at the upper layer. There is a strong resemblance between these furnaces. Furnace 2 and 3 were found at the lower layer. These furnaces are different from one another. The iron-smelting furnaces can be divided into three types by structures.

The Furnaces 1, 4, and 5 lie at regular intervals. This type

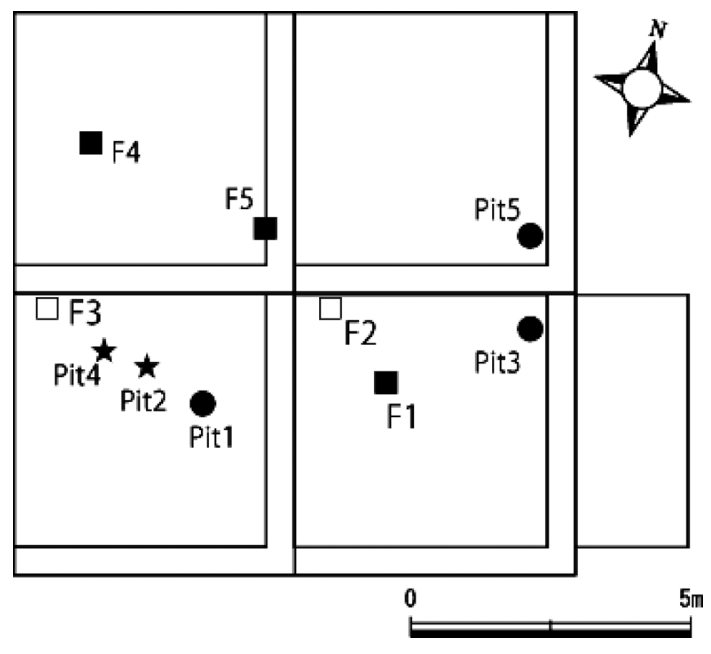

Fig. 3. Excavation area.

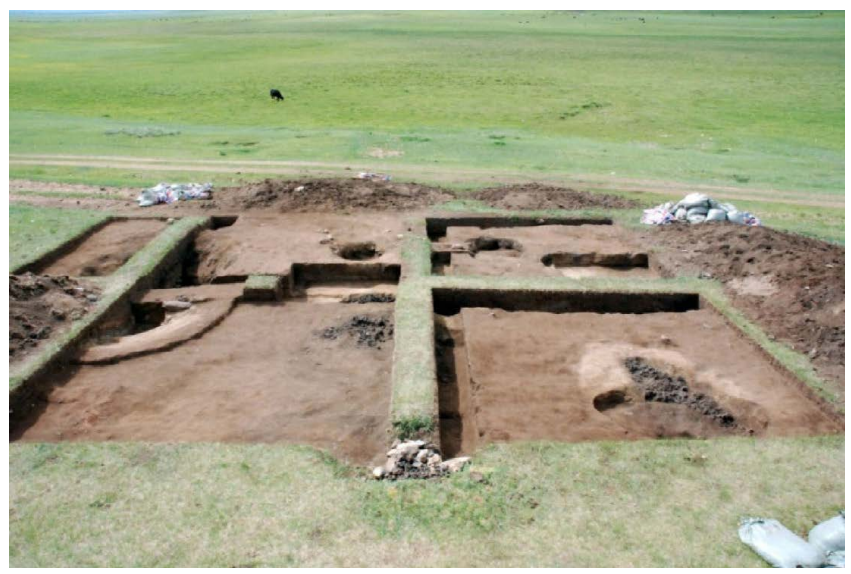

Fig. 4. Excavation area (from the north). (Online version in color.)

of furnace consists of two parts, a small square small pit (about $50 \mathrm{~cm} \times 50 \mathrm{~cm}$ ) and wide square or oval pit (about $200 \mathrm{~cm} \times 100 \mathrm{~cm}$ ) (Fig. 5). The small pit is a smelting furnace that has a square slag pit (depth $30 \mathrm{~cm}-40 \mathrm{~cm})$. The 


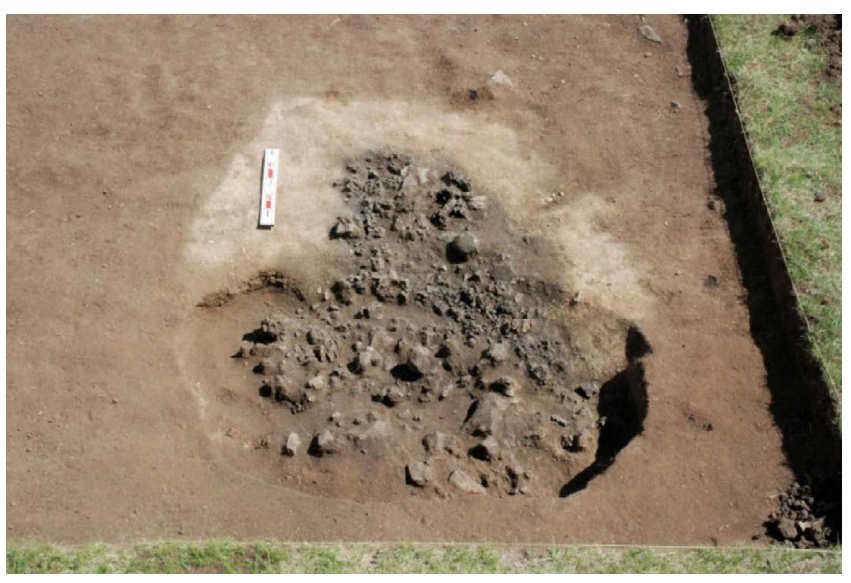

Fig. 5. Furnace 4 (from the north). (Online version in color.)

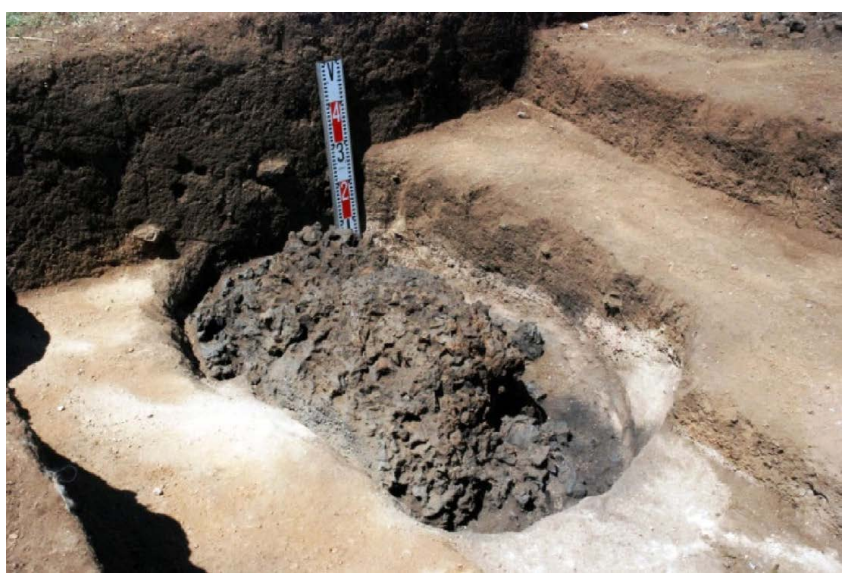

Fig. 6. Furnace 2 (from the northeast). (Online version in color.)

wide pit is a slag disposal pit, which was filled with slag (no tapping slag), furnace wall (mainly the lower part of furnaces), clay tuyeres and charcoal. Two charcoals in Furnace1 were analyzed by the ${ }^{14} \mathrm{C}$ analysis. The calibrated data $(2 \sigma$, 95.4\% probability) for Furnace1 are (1) 37BCE-30BCE, $1.6 \%$; 22BCE-11BCE, 3.2\%; 2BCE-80CE, 90.6\%, and (2) 21BCE-12BCE, 1.6\%; 1BCE-84CE; 93.8\%.

Furnace 2 has a large rectangular slag pit (about $100 \mathrm{~cm} \times$ $50 \mathrm{~cm}, 30 \mathrm{~cm}-40 \mathrm{~cm}$ depth) (Fig. 6). There is a very large amount of slag in this slag pit. We could not find a slag disposal pit like that of Furnace 4. Under the slag, we found not charcoal but ash. Therefore, we suppose this slag pit was filled with woods and branches before smelting. The calibrated data $(2 \sigma)$ of three charcoal in Furnace2 are (1) 103BCE-28CE, 94.1\%; 41CE-49CE, 1.3\%; (2) 160BCE$135 \mathrm{BCE}, 6.9 \%$; 115BCE-3CE, $88.5 \%$; and (3) 179BCE46CE, $95.4 \%$.

Furnace 3 was found in the north section of 2011's excavation area (Fig. 7). Therefore, we cannot determine its shape. This furnace has a narrow tunnel connecting a slag pit to the outside. The calibrated data $(2 \sigma)$ of the charcoal in Furnace 3 is 104BCE-31CE, 92.2\%; 37CE-52CE, 3.2\%.

\subsection{Calciner or Roaster Sites}

We found two curious pits (Pit2 and 4). These pits are small and almost square $(60 \mathrm{~cm} \times 80 \mathrm{~cm}, 50 \mathrm{~cm} \times 60 \mathrm{~cm})$ (Fig. 8), and are filled with very small iron ore (about $1 \mathrm{~cm}$ in

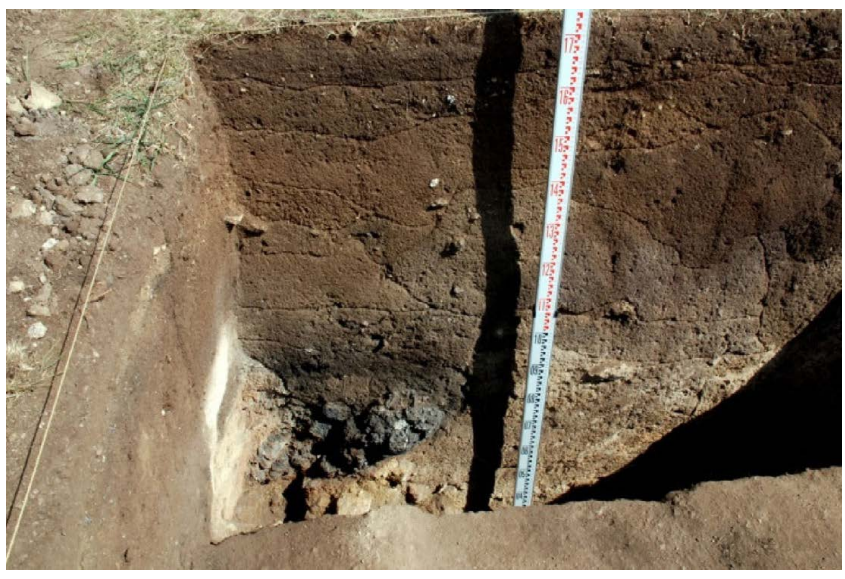

Fig. 7. Furnace 3 (from the south). (Online version in color.)

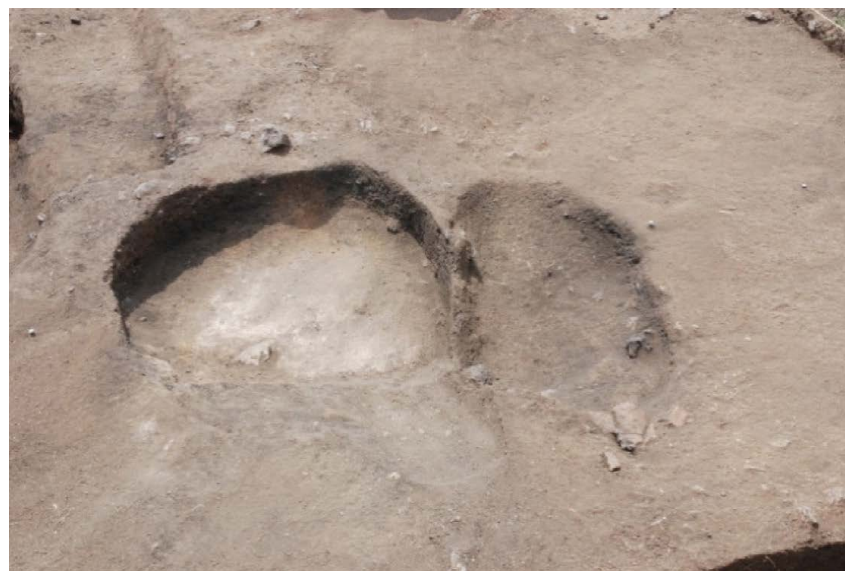

Fig. 8. Pit 2 (left) and Pit 4 (right). (Online version in color.)

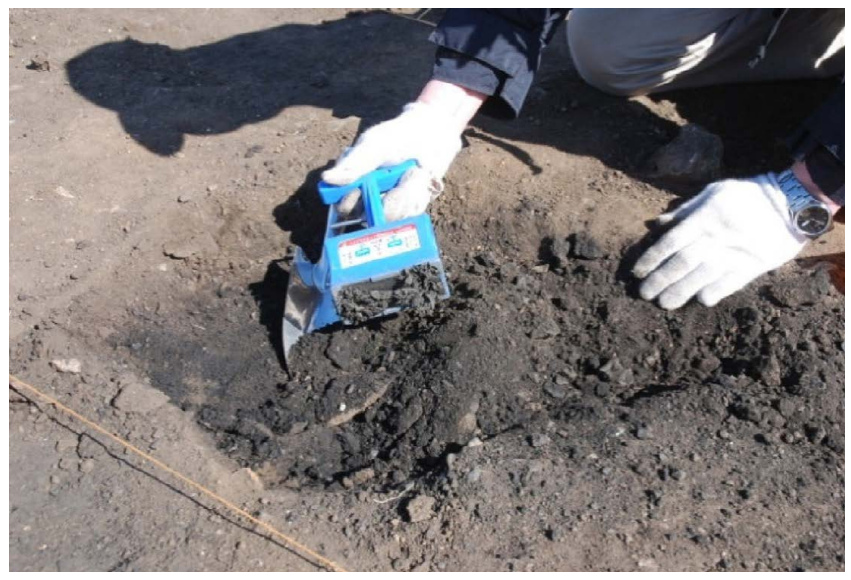

Fig. 9. Pit 2. (Online version in color.)

diameter), charcoal, ash and small pieces of granite (Figs. 9 and 10). The soil at the bottom of the pits had burned to red. The iron ore was quite magnetic. Because there was more ash than charcoal in these pits, it is obvious that not charcoal but wood was burned. We suppose that these pits were used as sites for calcining or roasting the iron ore (Magnetite $\rightarrow$ Maghemite $\rightarrow$ Hematite).

After washing these samples, we brought them back to Japan, to perform metallurgical and mineralogical analysis. The details of the analysis are given later. 


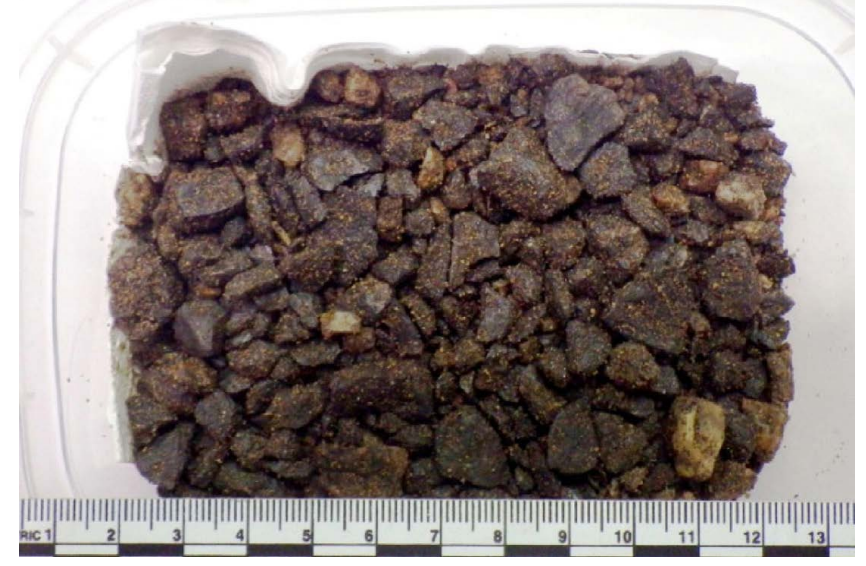

Fig. 10. Iron ore and granite. (Online version in color.)

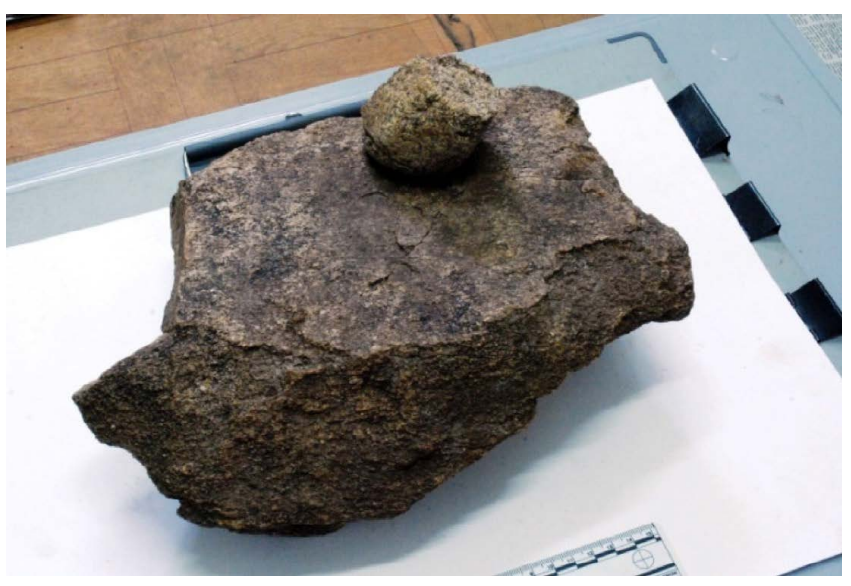

Fig. 11. Stone hammer and anvil. (Online version in color.)

The calibrated data $(2 \sigma)$ for the charcoal in Pit2 is 340BCE-329BCE, 1.7\%; 204BCE-54BCE, 93.7\%.

\subsection{Artifacts}

We found much slag, pieces of furnace wall and a few artifacts (stone tools, clay tuyeres and pottery). The stone tools consisted of hammers and anvils (Fig. 11), which were used to crush iron ore into pieces or to break the bloom to compare the iron with the slag.

A few pieces of pottery belonging to the Xiongnu age were discovered; no pottery from any other age was found.

There were many shards of clay tuyeres. These tuyeres were used at the smelting furnaces, not for casting and forging. Fortunately some clay tuyeres were well intact (Fig. 12). The tuyere sections are round in shape and have a maximum length of $16.6 \mathrm{~cm}$, an inside diameter at the tip of $3.2 \mathrm{~cm}$, and an outside diameter at the tip of $5.6 \mathrm{~cm}$. In addition, the inside diameters at the base are $7.2 \mathrm{~cm}-7.6 \mathrm{~cm}$, while the outside diameters at the base are $9.8 \mathrm{~cm}-10.2 \mathrm{~cm}$.

Sometimes clay tuyeres were stuck to furnace walls when unearthed. Based on observation of these samples (Fig. 13), it is obvious that several clay tuyeres were used at one smelting furnace in one operation. We can estimate the angles which the clay tuyeres were inserted to the furnace wall (Fig. 14).

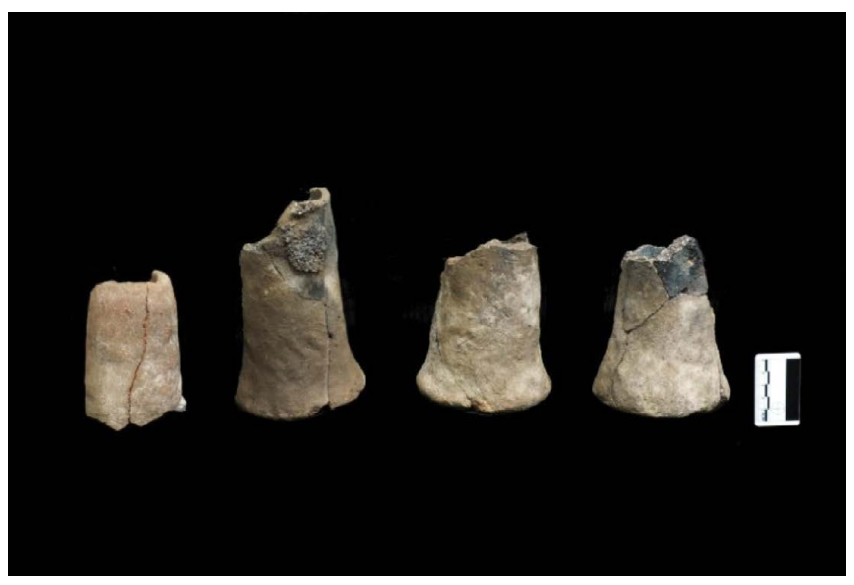

Fig. 12. Clay tuyeres. (Online version in color.)

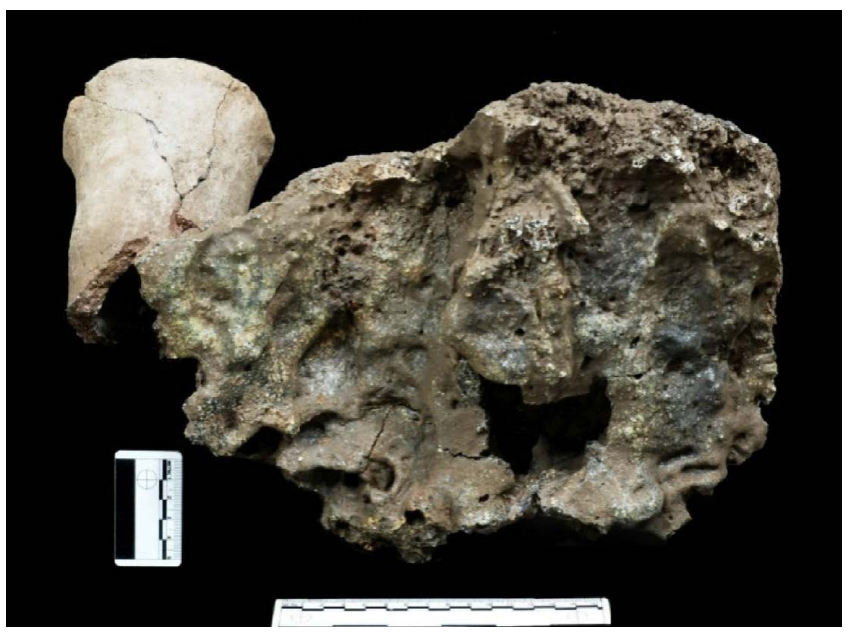

Fig. 13. Clay tuyeres and furnace wall. (Online version in color.)

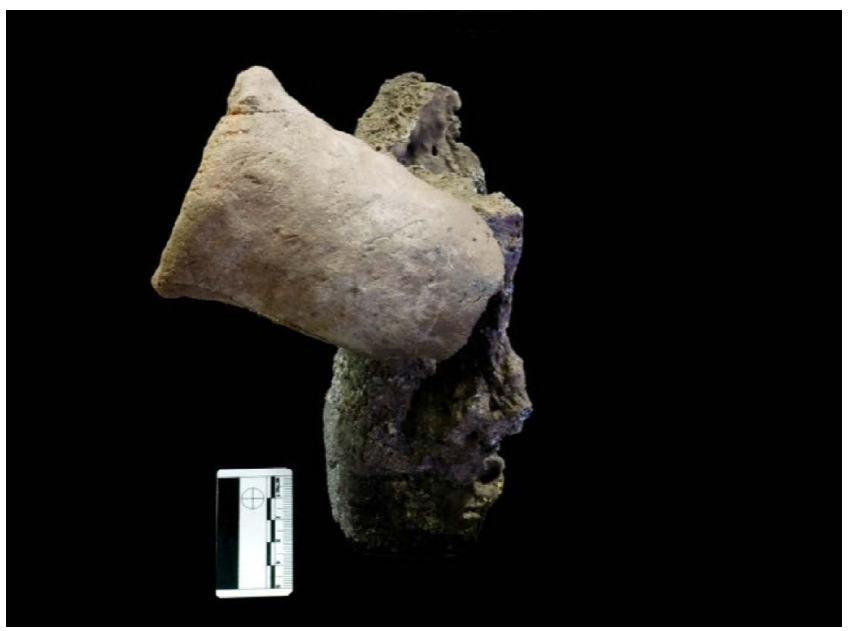

Fig. 14. Angles of insertion. (Online version in color.)

\section{Metallurgical Results}

\subsection{Iron Ore}

Prof. Izawa, Prof. Nakanishi and Mr. Osawa conducted metallurgical and mineralogical analyses of the iron ore. The purpose of these analyses was twofold: (1) to identify 


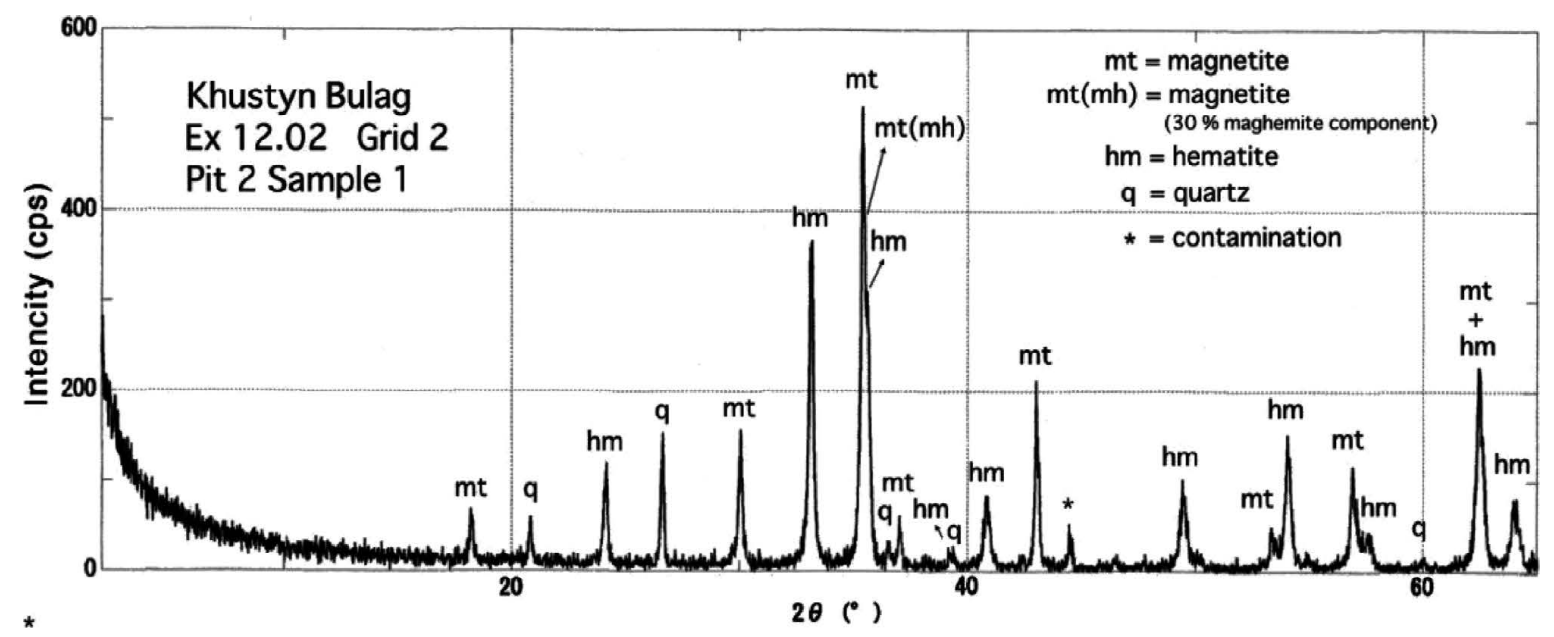

Fig. 15. Result of XRD.

Table 1. Chemical composition.

\begin{tabular}{|c|c|c|c|c|c|c|c|c|c|c|c|c|c|c|c|c|c|c|c|c|c|c|}
\hline $\begin{array}{c}\text { Sample } \\
\text { No }\end{array}$ & $\begin{array}{c}\text { Total } \\
\mathrm{Fe}\end{array}$ & $\begin{array}{c}\text { Metallic } \\
\mathrm{Fe}\end{array}$ & $\mathrm{FeO}$ & $\mathrm{Fe}_{2} \mathrm{O}_{3}$ & $\mathrm{SiO}_{2}{ }^{*}$ & $\mathrm{Al}_{2} \mathrm{O}_{3}{ }^{*}$ & $\mathrm{CaO}^{*}$ & $\mathrm{MgO}^{*}$ & $\mathrm{~K}_{2} \mathrm{O}^{*}$ & $\mathrm{Na}_{2} \mathrm{O}^{*}$ & $\mathrm{MnO}$ & $\mathrm{TiO}_{2}$ & $\mathrm{Cr}_{2} \mathrm{O}_{3}$ & $\mathrm{~S}$ & $\mathrm{P}_{2} \mathrm{O}_{5}$ & $\mathrm{C}$ & $\mathrm{CW}$ & V & $\mathrm{Cu}$ & $\mathrm{ZrO}_{2}$ & $\Sigma^{*}$ & $\begin{array}{c}\Sigma^{*} / \\
\text { Total Fe }\end{array}$ \\
\hline KB11-1 & 63.93 & 0.12 & 9.20 & 81.01 & 6.79 & 0.25 & 0.18 & 0.08 & 0.01 & 0.04 & 0.22 & 0.02 & 0.04 & 0.013 & 0.05 & 0.05 & $<0.01$ & 0.06 & $<0.01$ & - & 7.35 & 0.115 \\
\hline KB11-2 & 66.71 & 0.11 & 0.58 & 94.58 & 3.89 & 0.23 & 0.12 & 0.04 & $<0.01$ & 0.01 & 0.39 & 0.02 & 0.04 & 0.047 & 0.04 & $0.04<$ & $<0.01$ & $<0.01$ & $<0.01$ & - & 4.29 & 0.064 \\
\hline KB11-3 & 64.24 & 0.05 & 3.02 & 88.42 & 5.33 & 0.45 & 0.12 & 0.10 & 0.05 & 0.01 & 0.04 & 0.01 & 0.03 & 0.016 & 0.04 & $0.12<$ & $<0.01$ & 0.01 & $<0.01$ & - & 6.06 & 0.094 \\
\hline Pit2-1 & 52.23 & 0.07 & 8.62 & 65.00 & 13.34 & 0.55 & 10.04 & 0.30 & 0.01 & $<0.01$ & 0.92 & 0.03 & 0.05 & 0.001 & 0.07 & 0.09 & 0.41 & 0.01 & $<0.01<$ & $<0.012$ & 24.24 & 0.464 \\
\hline Pit2-2 & 66.10 & - & 16.59 & 76.07 & 200 & 121 & 0.21 & 0.59 & - & - & - & - & - & - & - & - & - & - & - & - & - & - \\
\hline Pit2-3 & 59.88 & - & 13.44 & 70.68 & - & - & - & - & - & - & - & - & - & - & - & - & - & - & - & - & - & - \\
\hline SG11- & 66.16 & 0.10 & 27.16 & 64.27 & 7.64 & 0.56 & 0.19 & 0.11 & $<0.01$ & $<0.01$ & 0.05 & 0.04 & 0.04 & 0.004 & 0.06 & 0.11 & - & $<0.01$ & $<0.01<$ & $<0.01$ & 8.50 & 0.128 \\
\hline
\end{tabular}

the iron mine that supplied the iron ore to the iron-smelting site, and (2) to clarify the function of Pit2 and 4.

Iron ore unearthed at the Khustyn Bulag site is mainly magnetite $\left(\mathrm{Fe}_{2} \mathrm{O}_{3} \cdot \mathrm{FeO}\right)$. Some hematite $\left(\alpha-\mathrm{Fe}_{2} \mathrm{O}_{3}\right)$ and maghemite $\left(\gamma-\mathrm{Fe}_{2} \mathrm{O}_{3}\right)$ has been confirmed by XRD analysis (Fig. 15). The iron ore is rich-grade ore $(52 \%-66 \%$ total $\mathrm{Fe})$ according to the chemical analysis (Table 1), with law values of sulfur $(0.001 \%)$ and phosphorus $(0.07 \%)$.

The mineralogical characteristics of the low value for $\mathrm{Al}_{2} \mathrm{O}_{3}$ indicate that the iron ore deposits are from the metamorphic sedimentary iron formation in the Pre-Cambrian (BIF), consisting of magnetite and quartz. Grunerite and greenalite represent the common silicates of such iron formation. We surveyed iron mine around the Khustyn Bulag site with Dr. Garamjav a very famous geologist in Mongolia. Although many kinds of iron ore were found around the site, there are no good iron deposits on the west side of the Kherlen River.

According to the mineral map, ${ }^{2)}$ good iron deposits are found on the east side of the Kherlen River. We visited the Ikh Gutain Gol iron deposit (2012) and the Bergiin Ovoo iron deposit (2013), and collected samples. We analyzed the sample collected at the Ikh Gutain Gol (Table 1). The sample (IGG11-1) is a candidate for the iron ore used at the Khustyn Bulag site because of its location and similarity of chemical characteristics. However the Bergiin Ovoo also has the same location and probably has similar chemical characteristics. Because the Bergiin Ovoo iron deposit is the

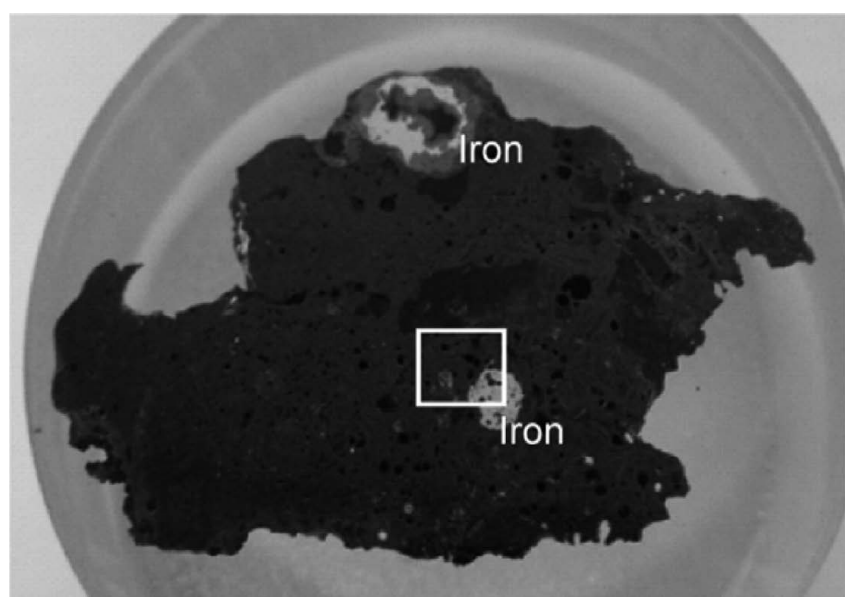

Fig. 16. Macro structure.

nearest iron deposit to the Khustyn Bulag site, we think this iron deposit was the iron mine that supplied iron ore to the iron-smelting site.

Iron ore unearthed at Pit2 contains small cracks, as revealed by microscopic analysis. Along these cracks, hematite was found. Maghemite and hematite were detected by XRF analysis. Therefore, there is a possibility that this iron ore was roasted and calcined in Pit 2 and Pit4, so they are the roasters or calciners. 


\subsection{Slag}

Prof. Izawa, Prof. Nakanishi and Mr. Osawa performed metallurgical and mineralogical analyses of the slag. The purpose of these analyses was to determine the characteristics of the iron-smelting technology. We picked up three samples and sent them to Japan.

Microscopic analysis revealed that the slag mainly consists of fayalite $\left(2 \mathrm{FeO} \cdot \mathrm{SiO}_{2}\right)$ which was crystallized by the slow cooling in the furnace, and a small amount of wustite (FeO), which was identified near small iron grains (Figs. 16 and 17). Iron droplets are low carbon steel, which consists of ferrite with very small amount of pearlite.

The chemical composition is $36.85 \% \mathrm{Fe}$ (total $\mathrm{Fe}$ ) and
$50.75 \% \quad \mathrm{SiO}_{2}+\mathrm{Al}_{2} \mathrm{O}_{3}+\mathrm{CaO}+\mathrm{MgO}+\mathrm{K}_{2} \mathrm{O}+\mathrm{Na}_{2} \mathrm{O}$. The very small value of $\mathrm{TiO}_{2}(0.32 \%), \mathrm{CrO}_{2}(0.02 \%), \mathrm{V}(0.01 \%)$ and $\mathrm{ZrO}_{2}(0.002 \%)$ indicate that iron ore (magnetite+quartz) was used for smelting.

Accoding to Fig. 18, slag mainly consisting of fayalite indicates an operating temperature of about $1100^{\circ} \mathrm{C}$. This temperature would produce bloom iron.

In coclusion, roasted iron ore and charcoal were used in direct steel-making process at the Khustyn Bulag site and bloom iron was produced.

These results are consistent with the work of Pro. Park, ${ }^{4,5)}$ who studied not slag but the iron implements of the Xiongnu age and came to the same conclusion.

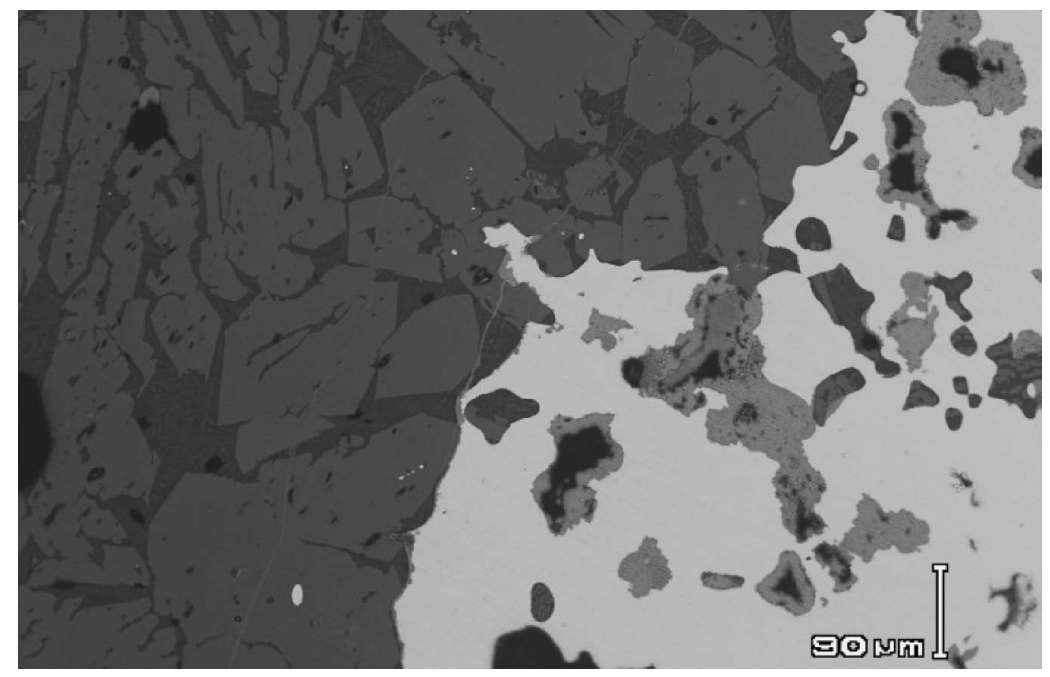

Fig. 17. Micro structure (close-up of the white square in Fig. 16). Left, fayalite; right, metal.

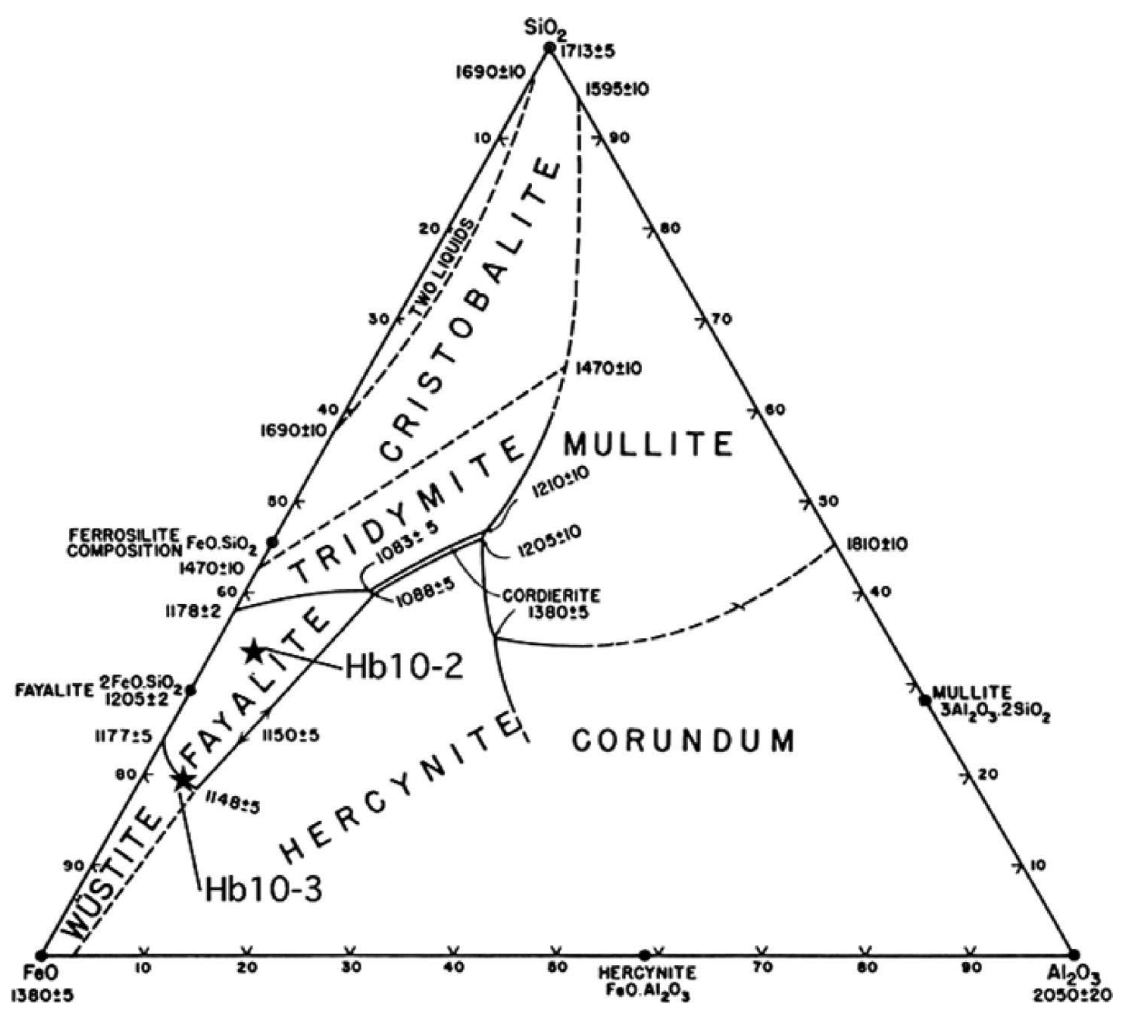

Fig. 18. System $\mathrm{Al}_{2} \mathrm{O}_{3}-\mathrm{FeO}-\mathrm{SiO}_{2}$ (modified after Ref. 3)). 


\section{Discussion}

The characteristics of iron smelting at the Khustyn Bulag site are as follows:

1. A direct steel making process was conducted.

2. Roasted or calcinated iron ore (Magnetite) was used as raw materials.

3. Charcoal was used as a fuel.

4. Bloom iron was produced.

5. Iron smelting was continued at the latest from the $1^{\text {st }}$ century BCE to the $1^{\text {st }}$ century CE.

6. Every furnace has a slag pit.

7. More than one small clay tuyere was used at one furnace in at least the $1^{\text {st }}$ century BCE (the upper layer).

8. Furnaces were built by clay. Stone or Wood was not used.

9. Stone tools (hammers and anvils) were used.

10. Only smelting process was carried. There was no evidence of refining, casting or forging (hammering).

These characteristics are different from those in the ancient central plains of China. The iron smelting in the Han dynasty (206BCE-220CE) is distinguished by a high shaft furnace, slag-tapping, pig iron production, and indirect steelmaking process. Judging from the existence of a slag pit and the use of small clay tuyeres, the iron smelting at the Khustyn Bulag site is similar to that at the Minusinsk basin in southern Siberia. ${ }^{6,7)}$ This technology spread from the west.

In Russia, Xiongnu iron-smelting has been reported around Lake Baikal. A "melting furnace" was reported at the Ivolga fortress south of Lake Baikal, in the Buryat Republic. ${ }^{8)}$ This fortress is a very famous Xiongnu fortress. Unfortunately, the excavation of the "melting furnace" occurred so long ago that the actual situation remains unclear.

In recent years, iron smelting has been studied west of Lake Baikal, in the Irkutsk. ${ }^{9)}$ A smelting furnace belonging to the same age as Xiongnu has found; it has a narrow tunnel connecting a slag pit with the outside. a characteristic shared by Furnace 3 at the Khustyn Bulag site. However, small clay tuyeres were not used around Lake Baikal.

\section{Conclusions}

In ancient Mongolia, iron was produced in the $1^{\text {st }}$ century $\mathrm{BCE}$ at the latest. We consider our research results sufficient to undertake a comparative study at Eurasia scale. Ironsmelting technology was introduced into ancient Mongolia from the West through the Steppe-Taiga area and was adjusted and locally developed.

We found no evidence of forging and casting. The produced iron was transported elsewhere, for the production of iron tools. We continue a general survey to find new archaeological sites such as in the Khanui Gol valley. ${ }^{10)}$

The Mongonmorit area contains many non-nomadic sites (fortresses, an iron-smelting site, pottery-making site, and tombs). We plan to survey the entire region in regard to steel manufacturing, ceramic industry, tombs, settlements, fortresses, etc. One of our goals is to reveal how the nomadic state adjusted to these non-nomadic factors and determine whether or not this adjustment was responsible for the rise and fall of the nomadic state, iron production is a venture that would conflict with their traditional nomadic life-style and surroundings.

Depending on the outcome of future research, our project will clarify the process that led nomadic society to produce a political system different from their original culture and to establish "nomadic state". 11)

\section{Acknowledgements}

This work was supported by Grant-in-Aid (KAKENHI) for Young Scientist (A), 23682010. Thanks go to the researchers at Ehime University (JAPAN) and at the Institute of Archaeology, Mongolian Academy of Sciences (Mongolia). We hope to continue our research with help and advice from many researchers in many countries.

\section{REFERENCES}

1) Kh. Perlee: Studia Archeologica., 9 (1982), 255 (in Mongolian).

2) Geological Information Center of MRAM: Mineral Deposits and Occurrences of Mongolia (Scale 1:1,000,000), Geological Information Center of MRAM, Ulaanbaatar, (2001).

3) J. Schairer and K. Yagi: Am. J. Sci., Bowen Volume (1952), Part 2, 471.

4) J. Park, Ch. Amartuvshin and G. Eregzen: J. Archaeol. Sci., 35 (2008), 2465.

5) J. Park, G. Eregzen and Ch. Yeruul-Erdene: J. Archaeol. Sci., 37 (2010), 2689.

6) Ya. Sunchungashev: Ancient Metall in Khakas, Nauka, Novosibirsk, (1979), (in Russian).

7) Y. Murakami and P. Amzarakov: 13th Meeting of the Research and Study in North Asia, Department of Archaeology, Univ. of Tokyo, Tokyo, (2012), 18 (in Japanese).

8) A. Davidova: Ivolga Archaeological Complex, Vol. 1, Fund "Asiatica", Sankt-Petersburg, (1995).

9) N. Kozhevnikov, A. Kharinsky and O. Kozhevnikov: J. Appl. Geophys., 47 (2001), 107.

10) J. Houle and L. Broderick: Xiongnu Archaeology - Multidisciplingary Perspectives of the First Steppe Empire in Inner Asia, Bonn University, Bonn, (2011).

11) I. Usuki: New Perspective on Xiongnu Studies in Ancient East Asian Culture, PKNU-KACAS Int. Conf. 2010, PKNU-KACAS, Seoul, (2010), 257. 